\title{
Deskripsi Makrofauna pada Tanah Andisol di Kabupaten Karo dengan Berbagai Ketebalan Abu Vulkanik Gunung Sinabung
}

\begin{abstract}
Description of Macrofaunal Communities at Different Thickness of Sinabung Volcanic Ash on Andisol Soil in Karo Regency
\end{abstract}

\section{Armando Septian Simbolon*, Mariani Sembiring, Tengku Sabrina}

Program Studi Agroekoteknologi, Fakultas Pertanian, Universitas Sumatera Utara, Medan 20155

*Corresponding author :ardoseptiansimbolon@gmail.com

\section{ABSTRACT}

Changed of soil conditions will result the changed population and diversity in the soil. The eruption of Sinabung Mount caused the surface of the soil covered with volcanic ash with various thickness. This research was to study description of macrofaunal communities at different thickness of Sinabung volcanic ash on andisol soil in Karo Regency. Experiment was conducted at May 2017. The experiment plot was located at four locations, location I was not covered by ash $(0 \mathrm{~cm})$, location II was covered with thin ash $(\leq 2 \mathrm{~cm})$, location III was covered with medium ash $(2-8 \mathrm{~cm})$, location $I V$ was covered with thick ash $(\geq 8 \mathrm{~cm})$ using the transect sampling method. Samplies was collected by using the Pitfall Trap, Monolith quadrant and the Hand Sorting method. Macrofaunal communities found 3 phyla, 6 classes, 11 order, 17 families, and 18 species at location $I$. Macrofaunal communities found 3 phyla, 7 classes, 11 orders, 16 families, and 17 species at location II. Macrofaunal communities found 2 phyla, 3 classes, 7 orders, 9 families, and 9 species at location III. Macrofaunal communities found 1 phylum, 2 classes, 5 orders, 7 families, and 7 species at location $I V$.

Keywords : Karo Regency, Soil macrofauna, Transect, Volcanic ash.

\begin{abstract}
ABSTRAK
Perubahan kondisi tanah akan berakibat ke populasi dan diversitas di dalam tanah. Letusan gunung Sinabung mengakibatkan permukaan tanah tertutupi abu vulkanik dengan berbagai ketebalan. Penelitian ini bertujuan untuk mengetahui deskripsi makrofauna tanah pada tanah andisol di Kabupaten Karo dengan berbagai ketebalan abu vulkanik gunung Sinabung, dilakukan pada bulan Mei 2017. Plot ditempatkan di empat lokasi, lokasi I tidak tertutupi abu $(0 \mathrm{~cm})$, lokasi II tertutupi abu tipis $(\leq 2 \mathrm{~cm})$, lokasi III tertutupi abu sedang $(2-8 \mathrm{~cm})$, lokasi IV tertutupi abu tebal $(\geq 8 \mathrm{~cm})$ dengan metode transek. Pengambilan sampel dilakukan dengan metode Pitfall Trap, Monolith kuadrat dan Hand Sorting. Lokasi I tidak tertutupi abu $(0 \mathrm{~cm})$ ditemukan 3 filum, 6 kelas, 11 ordo, 17 famili, dan 18 spesies. Lokasi II tertutupi abu tipis $(\leq 2 \mathrm{~cm})$ ditemukan 3 filum, 7 kelas, 11 ordo, 16 famili, dan 17 spesies. Lokasi III tertutupi abu sedang $(2-8 \mathrm{~cm})$ ditemukan 2 filum, 3 kelas, 7 ordo, 9 famili, dan 9 spesies. Lokasi IV tertutupi abu tebal $(\geq 8 \mathrm{~cm})$ ditemukan 1 filum, 2 kelas, 5 ordo, 7 famili, dan 7 spesies.
\end{abstract}

Kata kunci : Abu vulkanik, Kabupaten Karo, Makrofauna tanah, Transek.

\section{PENDAHULUAN}

Gunung Sinabung tercatat mengalami erupsi pada bulan September 2013, sebelumnya gunung ini sudah bererupsi yaitu pada tanggal 3 September 2010 (BPTP Sumatera Utara, 2013). Abu vulkanik akan melapuk menjadi bahan induk tanah dan selanjutnya akan mempengaruhi sifat dan ciri tanah yang akan terbentuk. Sifat-sifat tanah yang dipengaruhi yaitu sifat fisik, kimia serta biologi tanah. 
Hasil erupsi adalah salah satu bahan induk yang nantinya akan melapuk menjadi tanah. Abu vulkanik mengandung logam berat dan zat-zat mikro berbahaya bersifat mudah mengendap. Hasil analisis Balitbangtan (2014) $\mathrm{pH}$ tanah berkisar 4,4-6,5 sedangkan $\mathrm{pH}$ abu vulkan gunung Sinabung berkisar 3,3-3,5. pH tanah yang rendah dan endapan abu vulkanik akan mengganggu aktivitas organisme tanah karena terikatnya logam berat dan bersifat racun.

Abu vulkanik yang cukup lama menutupi permukaan tanah akan mengendap dan mengeras bergantung pada tingkat ketebalannya. Ini akan mempengaruhi aerasi tanah, respirasi, ketersediaan oksigen dan bahan organik dalam tanah yang berdampak pada kehidupan organisme dalam tanah. Jika semakin tebal abu yang menutupi tanah maka kandungan bahan organik akan mengalami penurunan, karena pada tanah yang terkena abu, organisme tanah sulit untuk bertahan hidup sehingga proses dekomposisi akan terhambat dan berpengaruh terhadap kandungan bahan organik tanah (Sinaga, 2015).

Makrofauna tanah dalam komunitasnya memiliki peran penting terhadap tanah yaitu dalam menyediakan peyeimbang ekosistem, memperbaiki aerasi dan drainase tanah, memperbaiki perkembangan akar pada tumbuhan, mendaur ulang bahan organik tanah, mendegradasi polutan, meregulasi komunitas tumbuhan, serta sebagian diantaranya berperan sebagai predator hama penyebab penyakit. Arthropoda tanah berperan penting dalam kesuburan tanah karena sebagai bioindikator perubahan lingkungan dan kesuburan tanah (Yulipriyanto, 2010)

Komunitas fauna tanah dipengaruhi oleh berbagai faktor lingkungan yaitu faktor biotik dan abiotik. Kedua faktor ini sangat menentukan komposisi fauna yang hidup disuatu habitat. Perbedaan distribusi dan kelimpahan fauna terutama adalah pengaruh dari perbedaan sifat fisika dan kimia lingkungan. Semakin tinggi keanekaragaman makrofauna tanah pada suatu tempat, maka semakin stabil ekosistem ditempat tersebut (Suin, 2006).

Berdasarkan uraian di atas maka perlu dilakukan penelitian mengenai komunitas makrofauna di tanah andisol yang tertutupi abu vulkanik gunung sinabung. Penelitian ini juga dihubungkan adanya perubahan sifat fisik kimia dan biologi tanah yang berkaitan dengan kehidupan makrofauna tanah.

\section{BAHAN DAN METODE}

Penelitian ini dimulai bulan Mei 2017 sampai dengan Oktober 2017 di Kecamatan Naman Teran Kabupaten Karo dan di Laboratorium Biologi Tanah, Program Studi Agroekoteknologi, Fakultas Pertanian Universitas Sumatera Utara, Medan dengan ketinggian tempat $\pm 25 \mathrm{~m}$ diatas permukaan laut.

Bahan yang digunakan dalam penelitian ini adalah sampel tanah yang tidak terkena abu vulkanik Sinabung dan tanah yang terkena abu dengan kedalaman 0-30 cm, alkohol 70\%, aquades, air steril dan diphenilamine, larutan $\mathrm{K}_{2} \mathrm{Cr}_{2} \mathrm{O}_{7}, \mathrm{H}_{2} \mathrm{SO}_{4}$ pekat, $\mathrm{H}_{3} \mathrm{PO}_{4} \quad 85 \%$, dan $\mathrm{FeSO}_{4} \quad 0,5 \mathrm{~N}$, deterjen untuk menyeimbangkan konsentrasi alkohol serta bahan-bahan kimia lain yang digunakan untuk analisis di laboratorium.

Alat yang dgunakan dalam penelitian ini adalah GPS (Global Position System), kamera digital, soil tester, soil termometer, monolith kuadrat, $\mathrm{pH}$ meter, spectrophotometer, bor tanah, corong plastik, timbangan analitik, pipet skala, cangkul, parang, pacak, terpal, karet gelang, botol sampel, ember plastik (diameter permukaan $15 \mathrm{~cm}$ ), kantong plastik, karung goni, pinset, spidol permanen, kertas data, buku catatan, pensil, meteran, kertas grafik dilaminating, loup, dan mikroskop stereo.

Penelitian ini dilakukan dengan menggunakan metode survei. Pengamatan yang dilakukan adalah dengan melihat 
makrofauna tanah yang ada, yang meliputi deskripsi makrofauna yaitu dengan Metode Pitfall Trap serta Metode Kuadrat dan Hand Sorting.

Pengambilan sampel tanah dilakukan hingga kedalaman 0-30 cm, Penentuan lokasi plot sampling dilakukan dengan metode transec. Setiap plot sampling ditempatkan dengan jarak yang telah ditentukan pada lahan tidak tertutupi dan tertutupi abu pada tempat yang dianggap mewakili keberadaan makrofauna tanahnya. Untuk tanah yang tidak terkena abu diambil di daerah pertanaman yang sudah diolah (lokasi I), sedangkan untuk sampel tanah yang tertutupi abu, pengambilan sampel dilakukan pada tanah yang tertutupi berbagai ketebalan abu sesuai dengan kriteria yang telah ditentukan yaitu tipis $\leq 2 \mathrm{~cm}$ (lokasi II), sedang $2-8 \mathrm{~cm}$ (lokasi III), dan tebal $\geq 8 \mathrm{~cm}$ (lokasi IV).

Pengambilan sampel makrofauna tanah yang aktif di permukaan tanah dilakukan dengan metode Pitfall Trap, yaitu: pada masing-masing titik sampling yang telah ditentukan, ditempatkan dan ditanam ember plastik berdiameter permukaan $15 \mathrm{~cm}$ sebanyak 10 ember dengan jarak antara ember satu dengan yang lainnya paling dekat $10 \mathrm{~m}$. Bagian permukaan ember tersebut ditanam sejajar dengan permukaan tanah dan selanjutnya ember-ember ini diberi atap dari terpal dengan ukuran $30 \times 30 \mathrm{~cm}$ setinggi \pm $15 \mathrm{~cm}$ dari tanah untuk menghindari masuknya air hujan dan sinar matahari ke dalamnya. Kemudian masing-masing ember diisi dengan larutan alkohol $70 \%$ sebanyak $\pm 250 \mathrm{ml}$ sebagai pembunuh dan pengawet serta dicampur dengan sedikit larutan deterjen untuk meniadakan tegangan permukaan pada larutan alkohol tersebut. Ember Pitfall Trap ini dipasang pada pukul 08.00 WIB dan diambil tiga hari berikutnya. Makrofauna tanah yang terperangkap dimasukkan ke dalam botol sampel sesuai dengan plotnya dan diawetkan dengan alkohol $70 \%$.
Metode kuadrat digunakan untuk pengambilan sampel makrofauna tanah yang kurang aktif di permukaan tanah tetapi lebih aktif di dalam tanah. Sampel tanah pada masing-masing titik sampling diambil sebanyak 8 plot menggunakan alat Monolith kuadrat ukuran $30 \times 30 \mathrm{~cm}$, tanah diambil sampai kedalaman $30 \mathrm{~cm}$. Jarak antara kuadrat satu dengan lainnya paling dekat $10 \mathrm{~m}$. Tanah yang diperoleh dimasukkan ke dalam goni plastik. Pengambilan sampel dilakukan antara pukul 06.00 - 09.00 WIB. Selanjutnya makrofauna tanah yang ditemukan pada tanah tersebut diambil dengan metode hand sorting (disortir dengan tangan) secara teliti. Makrofauna tanah yang didapat kemudian dikumpulkan dan dibersihkan dengan air lalu dimasukkan ke dalam botol sampel sesuai dengan plotnya dan diawetkan dengan alkohol $70 \%$. Selanjutnya semua sampel makrofauna tanah yang ditemukan dari metode Pitfall Trap dan Kuadrat dibawa ke Laboratorium Biologi Tanah Program Studi Agroekoteknologi untuk diidentifikasi.

Sampel makrofauna tanah yang dibawa dari lapangan dikelompokkan sesuai dengan kesamaan ciriciri morfologinya kemudian diawetkan dalam alkohol 70\%. Proses determinasi dan identifikasi dilakukan dengan memperhatikan morfologi (bentuk luar tubuhnya) melalui loup dan mikroskop stereo serta menggunakan beberapa buku acuan.

\section{HASIL DAN PEMBAHASAN}

Berdasarkan hasil penelitian yang telah dilakukan pada empat lokasi yaitu lokasi I (tidak tertutupi abu), lokasi II (tertutupi abu tipis), lokasi III (tertutupi abu sedang) dan lokasi IV (tertutupi abu tebal) ditemukan berbagai macam makrofauna tanah dapat dilihat pada gambar - gambar dibawah ini. 


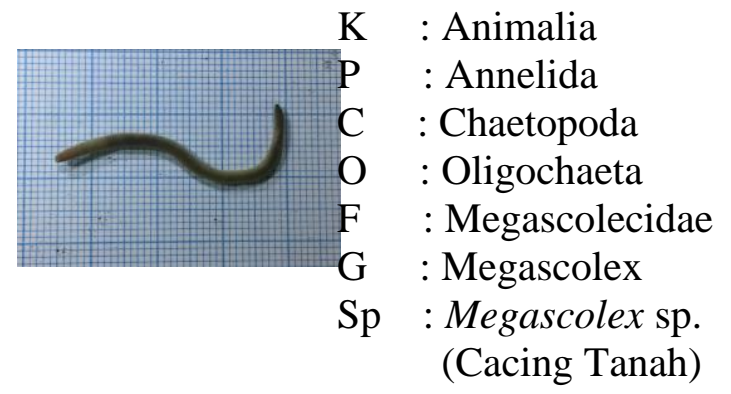

Panjang tubuh 9 - $13 \mathrm{~cm}$, lebar tubuh 0,3 $0,4 \mathrm{~cm}$ dengan jumlah segmen antara 134 178. Prostomium tipe Epilobus. Klitelium berbentuk Annular dimulai pada segmen ke 14-16, mempunyai setae dengan tipe Perichaetine. Lubang kelamin jantan pada segmen 18 , betina pada segmen 7 - 9. Warna bagian dorsal merah keunguan, ventral pucat atau coklat keputihan. ujung anterior coklat keputihan dan ujung posterior abu-abu coklat.

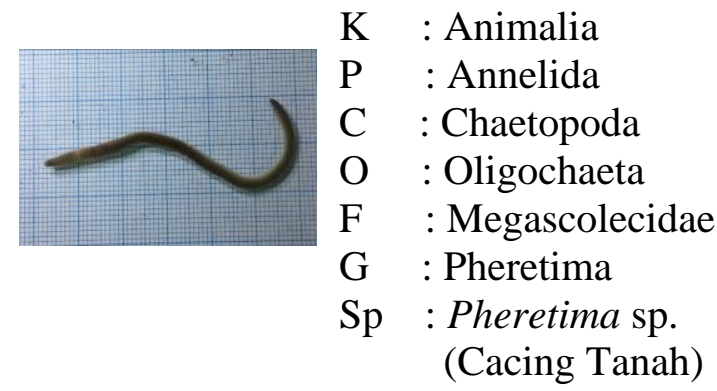

Panjang tubuh $15-18,5 \mathrm{~cm}$, lebar tubuh 0,5 $-0,6 \mathrm{~cm}$. Jumlah segmen antara $125-145$. Prostomium tipe Epilobus. Klitelium berbentuk Annular dan tidak menebal pada segmen ke 13 - 15, segmennya jelas. Setae dengan tipe Perichaetin. Lubang kelamin jantan pada segmen ke 18 dan satu lubang betina di segmen ke 14. Warna tubuh bagian dorsal coklat keunguan, ventral pucat, ujung anterior coklat sampai pucat/kuning.

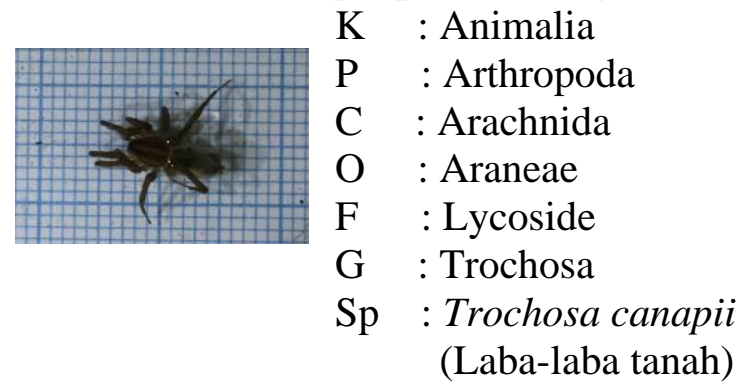

Panjang tubuh $1-1,1 \mathrm{~cm}$, lebar tubuh 0,3 $\mathrm{cm}$. Memiliki 8 pasang mata. Memiliki 4 pasang kaki dengan panjang rata-rata 0,8 $\mathrm{cm}$. Chepalothoraks memiliki pola yang khas (pada kebanyakan Genus dari Family
Lycosidae).Warna tubuh cokelat kecuali pada bagian cephalothoraks dan abdomen yang agak gelap.

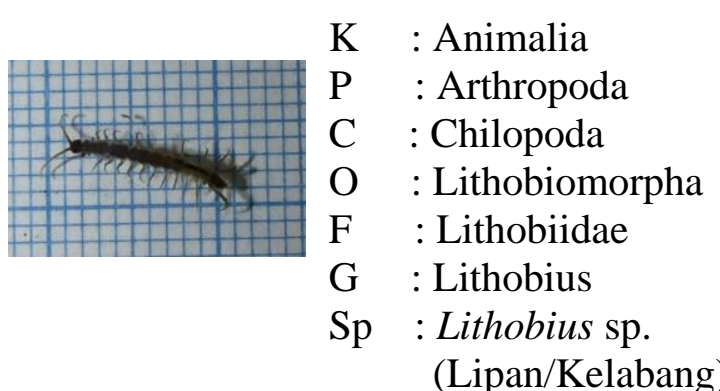

Panjang tubuh $1-1,2 \mathrm{~cm}$, lebar tubuh 0,1 $0,2 \mathrm{~cm}$. Caput bulat dan pendek dan terdapat sepasang mata dan antena yang panjang. Bagian mulut terdapat sepasang capit dengan tipe pengunyah. Memiliki $10-15$ segmen pada bagian abdomen, segmen memiliki 2 bentuk, lebar dan sempit, kedua segmen tersebut berseling membentuk tubuh, ujung abdomen terdapat sepasang cerci yang panjang. Tubuh seutuhnya berwarna merah kecokelatan.

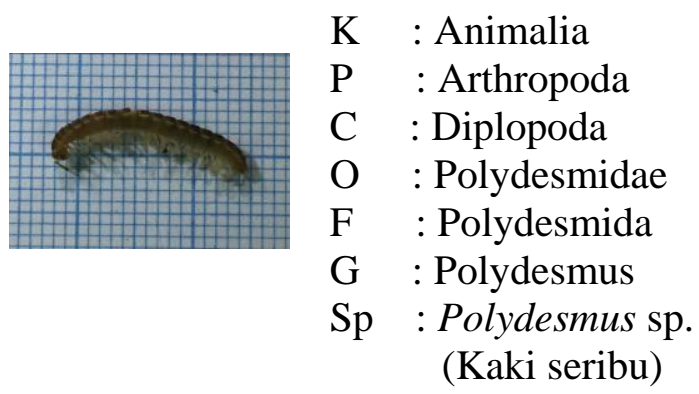

Panjang tubuh 1,5 - $2 \mathrm{~cm}$, lebar tubuh 0,3 $\mathrm{cm}$. Cepalothoraks agak membulat, terdapat sepasang mata dan antena yang pendek, dengan mulut tipe pengunyah. Memiliki 17 - 20 segmen, tepi segmen memipih, tiap segmen dijumpai 2 pasang kaki kecuali pada segmen terakhir. Ujung abdomen terdapat ovipositor agak meruncing. Warna tubuh cokelat kehitaman, kaki putih. melindungi diri dengan menggulungkan tubuhnya jika merasa terancam.

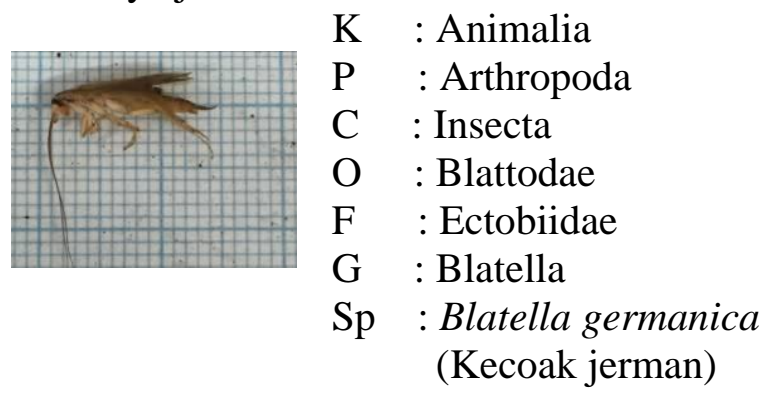


Panjang tubuh $1,2 \mathrm{~cm}$, lebar tubuh $0,4 \mathrm{~cm}$. Tubuh lonjong dan agak tipis. Kepala pipih. Mata jelas terlihat. Memiliki antena yang panjang hingga $0,7 \mathrm{~cm}$. Pronotum dengan abdomen sejajar. Memiliki sepasang sayap yang tipis. Pada bagian ujung abdomen dijumpai sepasang cerci. Kaki cukup jenjang dan terdapat duri halus pada bagian tibia. Warna tubuh seluruhnya cokelat.

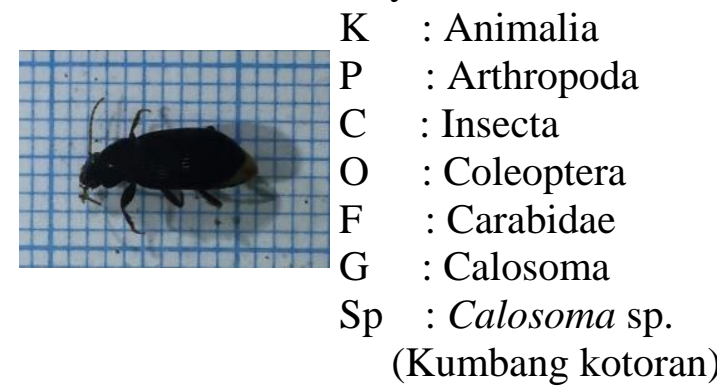

Panjang tubuh 0,9 - 1,2 cm, lebar tubuh 0,35 - 0,4 cm. Caput terdapat sepasang mata dan antena yang panjang dan terdiri atas 14 ruas. Mata jelas terlihat. Mulut tipe penggigit pengunyah. Batas pronotum bulat pendek. Pada elytra terdapat garis-garis. Kaki 3 pasang yang terdiri atas, koksa, trokanter, femur, tibia, tarsal (3 ruas) dan metatarsal, tubuh berwarna metalik gelap.

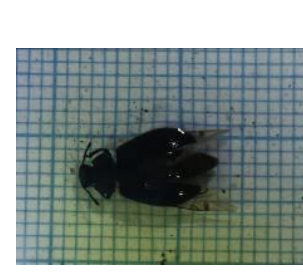

$$
\begin{array}{ll}
\mathrm{K} & : \text { Animalia } \\
\mathrm{P} & : \text { Arthropoda } \\
\mathrm{C} & : \text { Insecta } \\
\mathrm{O} & : \text { Coleoptera } \\
\mathrm{F} & : \text { Carabidae } \\
\mathrm{G} & : \text { Stenolophus } \\
\mathrm{Sp} & : \text { Stenolophus } \mathrm{sp} .
\end{array}
$$$$
\text { (Kumbang jamur) }
$$

Panjang tubuh $0,9-1,2 \mathrm{~cm}$, lebar tubuh 0,3 $\mathrm{cm}$. Tubuh agak pipih. Caput lonjong dengan mata yang jelas. Memiliki sepasang mata yang menonjol pada bagian kepala. Antena tersusun atas 10 ruas. Pronotum agak gepeng. Elitra membulat kebelakang dengan garis-garis kasar disertai rambut halus dan jarang pada bagian tepi. Kaki 3 pasang terdiri atas koksa, trokanter, femur, tibia, tarsal (3 ruas) dan metatarsal, kaki memiliki duri-duri dan rambut halus. Warna tubuh dominan hitam disertai warna hijau metalik, pada bagian tepi pronotum dan bagian kaki berwarna kuning.

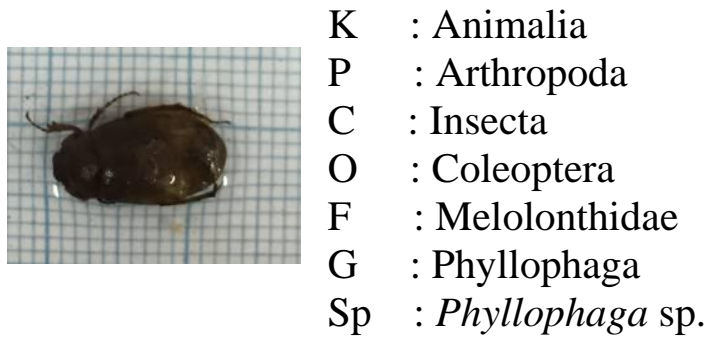

(Kumbang tanah)

Panjang tubuh $0,9-1,1 \mathrm{~cm}$, lebar tubuh 0,5 $\mathrm{cm}$. Tubuh kokoh berbentuk bulat lonjong dan tebal. Caput bulat dan agak pipih. Mulut tipe pengunyah, antena bercabang 3 . Pronotum dan elytra sejajar dengan batas yang jelas. Ujung elytra tumpul dan sedikit membulat. Tubuh berwarna kuning kegelapan, coklat kemerahan sampai hitam dan terkadang berwarna metalik.

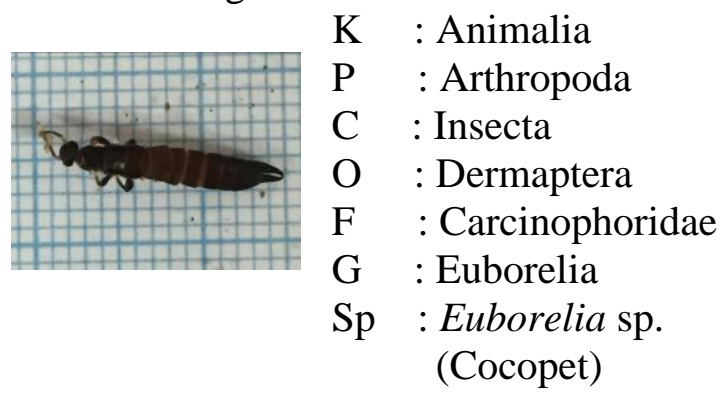

Panjang tubuh 2,5 - $3 \mathrm{~cm}$, lebar tubuh 0,4 $\mathrm{cm}$. Caput berbentuk seperti segitiga berwarna hitam. Mempunyai sepasang mata berwarna putih. Antena 16 ruas, ruas 13 dan 14 warna putih. Mulut tipe penggigit dan pengunyah. Terdapat palpus dengan warna agak kecoklatan berjumlah 2 ruas. Thoraks berwarna cokelat kehitaman. Tungkai depan dan tengah berjumlah 3 ruas, tungkai belakang 4 ruas. Abdomen berjumlah 8 ruas berwarna cokelat kehitaman, memiliki sepasang cerci untuk mencapit pada bagian belakang. Tubuh seluruhnya berwarna kehitaman.

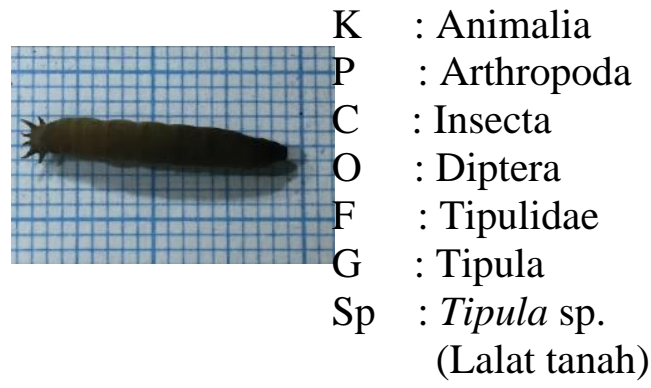


Larva: Panjang tubuh 1,6 - 1,8 cm, lebar 2 $\mathrm{cm}$. Bentuk bulat memanjang dan terlihat seperti bersegmen, bagian kepala memiliki bagian menyerupai tanduk sebanyak 3 pasang dengan mulut agak menonjol, tubuh bagian bawah lebih ramping. Warna tubuh cokelat. Dewasa: Panjang tubuh 1,7 $-2 \mathrm{~cm}$, lebar $0,2 \mathrm{~cm}$. Tubuh ramping dan meruncing ke belakang. Memiliki sepasang sayap dan 3 pasang kaki yang panjang. Warna tubuh kuning kecokelatan.

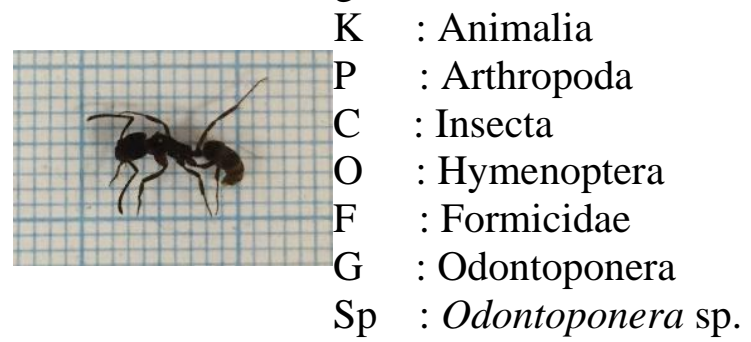
(Semut hitam)

Panjang tubuh $0,8-1,1 \mathrm{~cm}$, lebar tubuh 0,3 $\mathrm{cm}$. kepala agak membulat, rahang pendek dan kokoh. Keliling clypeal hadapan mempunyai 7 - 9 gigi dengan berbagai bentuk dari tumpul ke tajam. Antena 12 ruas, mata jelas. Pronotum mempunyai sepasang gigi berbentuk segitiga di sisi tubuh. Memiliki 1 pentiole yang tipis dan menajam. Warna tubuh hitam dengan pola garis yang khas.

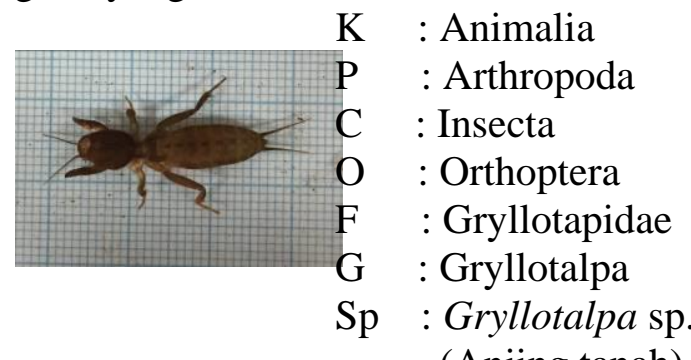

(Anjing tanah)

Panjang tubuh 2,5 - $3 \mathrm{~cm}$, lebar tubuh 0,5 $0,8 \mathrm{~cm}$, caput agak mengerucut kedepan, mata bulat dengan antena yang pendek, mulut memiliki sepasang capit menyerupai gergaji yang digunakan untuk memotong. Pronotum besar, bagian thoraks dijumpai 3 pasang kaki, sepasang kaki depan yang berukuran lebih besar memiliki kuku yang termodifikasi untuk menggali. Memiliki dua pasang sayap, abdomen terdiri atas $6-7$ lipatan, tubuh berwarna cokelat dan agak sedikit gelap pada bagian kepala.

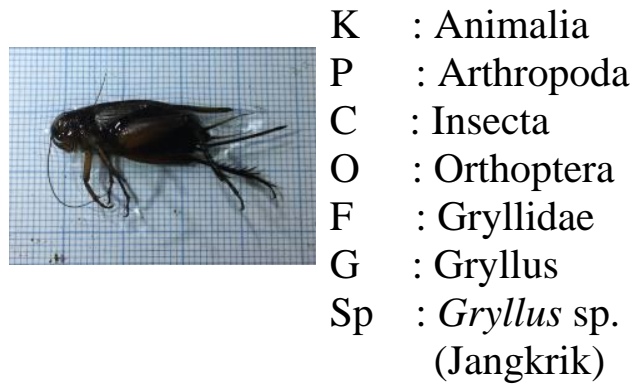

Panjang tubuh 3,2 cm, lebar tubuh $1 \mathrm{~cm}$. Kepala bulat, terdapat sepasang mata dan antena yang panjangnya $\pm 1 \mathrm{~cm}$. Pada bagian thoraks terdapat 3 pasang kaki, sepasang kaki belakang lebih besar dan pajang dari 2 pasang kaki depannya yang termodifikasi untuk melompat. Sayap pendek. Bagian abdomen beruas-ruas antara 8 - 10 ruas, pada abdomen terakhir terdapat sepasang cerci dan ovipositor. Warna tubuh hitam kecuali bagian kaki dan sayap yang berwarna cokelat. Mengeluarkan suara keras di malam hari.

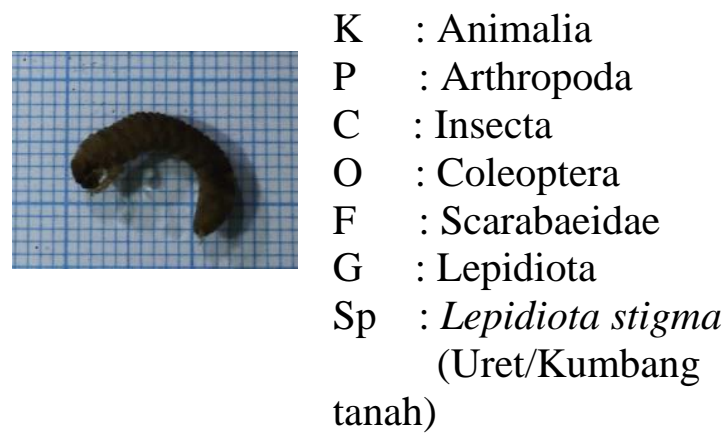

Larva: Panjang tubuh 1-4 cm, lebar 5-10 $\mathrm{mm}$. Bentuk tubuh bulat memanjang dan memiliki kepala berwarna coklat pucat. Warna tubuh putih kecokelat berbentuk seperti huruf c. Dewasa: Panjang tubuh 3,5$5 \mathrm{~cm}$, bagian dorsal menebal berwarna coklat pucat, memanjang, bersisik tebal dan sebuah ambalan kecil yang tebal.

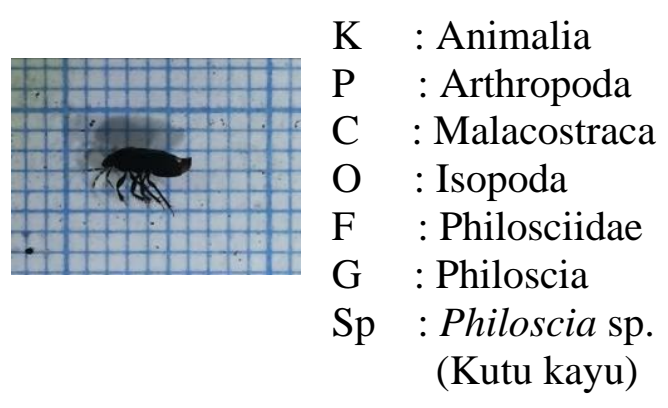


Panjang tubuh $0,7-1 \mathrm{~cm}$, lebar tubuh $0,2-$ $0,3 \mathrm{~cm}$. Caput pendek, terdapat sepasang mata dan antena yang panjang, dengan mulut tipe pengunyah. Thoraks terdapat 7 segmen. Abdomen terdapat 5 segmen, pada ujungnya terdapat sepasang cerci dan ovipositor yang runcing. Segmen bentuknya melengkung kebawah, tiap segmen pada thoraks dijumpai sepasang kaki, dua pasang kaki bagian belakang memiliki ukuran lebih panjang daripada kaki lainnya. Warna tubuh bagian dorsal gelap, warna tubuh bagian ventral kuning kecokelatan.

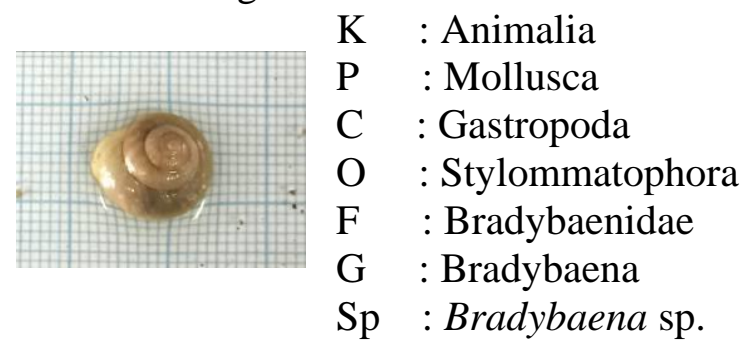

(Siput darat)

Tinggi cangkang $0,8-1,1 \mathrm{~cm}$, lebar cangkang 1,6 - 1,8 cm. Tipe cangkang Depresed heliciform. Whorl pada cangkang berjumlah $51 \frac{1}{2}$. Umbilicus sempit. Parietal kurang jelas terlihat. Cangkang tipis dan teksturnya halus. Terdapat sebuah garis spiral yang mengelilingi cangkang. Dinding cangkang rapuh, garis-garis pertumbuhan kurang jelas telihat. Warna cangkang cokelat kekuningan.

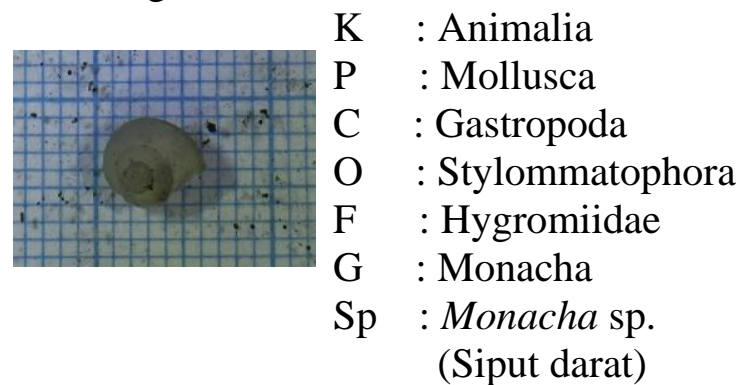

Tinggi cangkang 0,9-1 cm, lebar cangkang 1,5-1,8 cm. Tipe cangkang Depressed heliciform. Jumlah whorl pada cangkang 5 1/2. Umbilicus sempit. Parietal kurang jelas terlihat. Cangkang tipis dan teksturnya kasar. Dinding cangkang rapuh dan memiliki garis-garis pertumbuhan yang mengeriput dan jelas. Bagian atas cangkang berwarna agak keputihan dan semakin cokelat menuju ke pangkal.

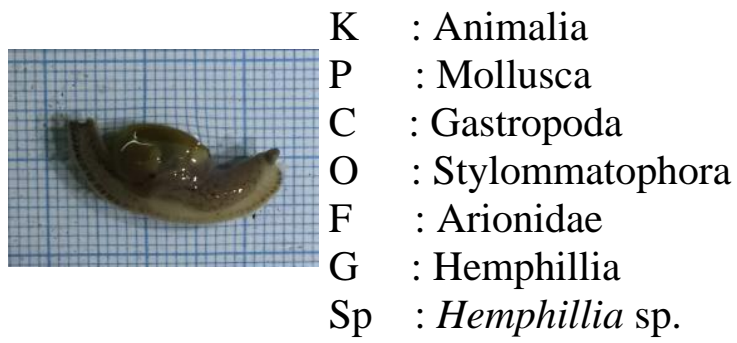

(Siput telanjang)

Panjang tubuh 2,8 - 3,3 cm, lebar tubuh 0,8 $1,1 \mathrm{~cm}$. Bagian kepala bulat dengan 2 pasang mata. Memiliki punuk viseral yang berbeda dan dilapisi oleh mantel pada bagian anterior dan posterior. Memiliki sedikit cangkang ditengah yang terlihat melalui celah dibelakang mantel. Bagain belakang bentuknya lebih meruncing. Pneumastome terletak dibawah punuk viseral. Warna tubuh keseluruhan berwarna cokelat.

Data pada gambar - gambar diatas memperlihatkan makrofauna tanah yang ditemukan pada berbagai lokasi penelitian. Pada lokasi I (tidak tertutupi abu) terdiri atas 18 spesies yaitu Megascolex sp., Pheretima sp., Trochosa canapii, Polydesmus sp., Blattella germanica, Calosoma sp., Stenolophus sp., Phyllophaga sp., Lepidiota stigma, Euborellia sp., Tipula sp., Odontoponera sp., Gryllotalpa sp., Gryllus sp., Philoscia sp., Hemphillia sp., Bradybaena similaris, Monacha sp. Pada lokasi II (tertutupi abu tipis) terdiri atas 17 spesies yaitu Megascolex sp., Pheretima sp., Trochosa canapii, Lithobius sp., Polydesmus sp., Calosoma sp., Stenolophus sp., Lepidiota stigma, Euborellia sp., Tipula sp., Odontoponera sp., Gryllotalpa sp., Gryllus sp., Philoscia sp., Hemphillia sp., Bradybaena similaris, Monacha sp. Pada lokasi III (tertutupi abu sedang) terdiri atas 9 spesies yaitu Pheretima sp., Trochosa canapii, Blattella germanica, Calosoma sp., Lepidiota stigma, Euborellia sp., Odontoponera sp., Gryllotalpa sp., Gryllus sp. Pada lokasi IV (tertutupi abu tebal) terdiri atas 7 spesies yaitu Trochosa canapii, Calosoma sp., Lepidiota stigma, Euborellia sp., Odontoponera sp., 
Gryllotalpa sp., Gryllus sp. Ini menggambarkan semakin tebal abu vulkanik yang menutupi tanah semakin rendah jumlah spesies yang ditemukan. Filum arthropoda mendominasi dan ditemukan di semua lokasi. Mendominasinya filum arthropoda yang ditemukan dikarenakan filum tersebut merupakan filum terbesar dengan jumlah anggota terbanyak dari kingdom animalia (Campbell and Reece, 2010).

Spesies makrofauna tanah yang hanya ditemukan pada masing-masing lokasi tersebut juga berbeda. Dari total 18 spesies makrofauna tanah yang ditemukan pada lokasi I (tidak tertutupi abu), jumlah spesies makrofauna tanah yang hanya ditemukan pada lokasi ini berjumlah 1 spesies, yaitu: Phyllophaga sp. (Kumbang tanah). Pada lokasi II (tertutupi abu tipis) dari total 17 spesies yang ditemukan, jumlah spesies makrofauna tanah yang hanya ditemukan pada lokasi ini berjumlah 1 spesies, yaitu: Lithobius sp. (Lipan) Pada lokasi III (tertutupi abu sedang) ditemukan 9 spesies dan lokasi IV (tertutupi abu tebal) 7 spesies yang ditemukan, jumlah spesies makrofauna tanah yang hanya ditemukan pada kedua lokasi berjumlah 0 spesies atau tidak ada.

Spesies Phyllophaga sp. (Kumbang tanah) hanya ditemukan pada lokasi I (tidak tertupi abu) diduga karena beberapa spesies Phyllophaga sp. lebih menyukai habitat yang kadar air dan bahan organik tinggi, dapat dilihat pada Tabel 1 bahwa kadar air dan bahan organik tertinggi yaitu pada lokasi I (tidak tertutupi abu). Hal ini sesuai pernyataan Michael (1995) banyak fauna-fauna darat seperti isopoda, sejumlah insecta, dan arthropoda lainnya hanya ditemukan pada habitat-habitat dengan kadar air yang cukup tinggi. Spesies Lithobius sp. (Lipan) merupakan spesies yang unik, ini dikarenakan mereka memiliki distribusi yang cukup membingungkan. Untuk memahami kecenderungan populasi, status spesies, dan hubungan habitat, para peneliti saat ini mencoba untuk memahami perbedaan dan persamaan antara habitat, ekologi, dan biologinya (Burke, 2005). Adapun faktor yang mempengaruhi jumlah spesies yang hanya ditemukan pada masing-masing lokasi diantaranya adalah aktivitas dan kemampuan tiap spesies makrofauna tanah yang berbeda antara satu dengan yang lain (Hanafiah et al., 2005) serta dipengaruhi jenis tanaman yang ditanam (Sugiyarto, 2005).

Berdasarkan 5 kelas pada filum arthropoda tersebut yang paling banyak ditemukan adalah pada kelas insecta Banyaknya makrofauna tanah dari kelas insecta yang ditemukan pada semua lokasi karena insecta merupakan kelompok fauna yang jumlah spesiesnya banyak dan penyebarannya sangat luas. Penelitian mengenai makrofauna tanah seperti yang telah dilakukan oleh Wibowo dan Syamsudin (2017) juga menunjukkan bahwa makrofauna tanah dari kelas insecta merupakan yang paling banyak ditemukan dari kelas makrofauna tanah lainnya.

Spesies Megascolex sp., Pheretima sp., dan Philoscia sp. merupakan makrofauna tanah Saprophagous yang membutuhkan bahan organik yang cukup sebagai makanannya, menurut Hanafiah et al. (2005) Megascolex sp. mampu hidup pada $\mathrm{pH}$ diatas 4,5. Lokasi I (tidak tertutupi abu) dan II (tertutupi abu tipis) menyediakan hal tersebut sesuai. Sementara itu, spesies Lithobius sp., merupakan makrofauna tanah Carnivore yang bahan makanannya berupa hewan lain namun hanya ditemukan pada lokasi II (tertutupi abu tipis). Hal tersebut dikarenakan Lithobius sp. membutuhkan bahan organik yang cukup sebagai habitatnya meskipun tidak memakannya. Polydesmus sp., Stenolophus sp., Hemphillia sp., Bradybaena similaris, Monacha sp. merupakan makrofauna Phytophagous pemakan tumbuhan. Ini sesuai pernyataan Hanafiah et al., (2005) Makrofauna tanah terdiri atas kelompok herbivora dan karnivora. Herbivora meliputi annelida seperti cacing, mollusca seperti bekicot dan keong. arthropoda 
meliputi crustacea seperti kepiting dan diplopoda seperti kaki seribu. Spesies tersebut hanya terdapat pada lokasi I (tidak tertutupi abu) dan II (tertutupi abu tipis) dikarenakan pada lokasi tersebut tingkat keanekaragaman vegetasi yang tinggi. Spesies Tipula sp. menurut Wallwork (1970) dalam Suin (2006) merupakan makrofauna tanah yang bersifat Temporary yang meletakkan telurnya di tanah. Telur-telur tersebut membutuhkan bahan organik sebagai makanan untuk pertumbuhannya. Oleh karena itu Tipula sp. tidak dapat hidup dilokasi III (tertutupi abu sedang) dan lokasi IV (tertutupi abu tebal) karena pada kedua lokasi tanah tertutupi abu vulkanik yang tebal sehingga Tipula sp. tidak dapat meletakkan telurnya.

\section{SIMPULAN}

Pada lokasi yang tidak tertutupi abu $(0 \mathrm{~cm})$ ditemukan 3 filum, 6 kelas, 11 ordo, 17 famili, dan 18 spesies. Pada lokasi tertutupi abu tipis $(\leq 2 \mathrm{~cm})$ ditemukan 3 filum, 7 kelas, 11 ordo, 16 famili, dan 17 spesies. Pada lokasi tertutupi abu sedang $(2-8 \mathrm{~cm})$ ditemukan 2 filum, 3 kelas, 7 ordo, 9 famili, dan 9 spesies. Pada lokasi tertutupi abu tebal $(\geq 8 \mathrm{~cm})$ ditemukan 1 filum, 2 kelas, 5 ordo, 7 famili, dan 7 spesies.

\section{DAFTAR PUSTAKA}

BPTP Sumatera Utara, 2013. Rekomendasi Kebijakan Mitigasi Erupsi Sinabung terhadap Sektor Pertanian. Medan.

Balitbangtan. 2014. Hasil Kajian dan Identifikasi Dampak Erupsi Gunung Sinabung pada Sektor Pertanian. Badan Penelitian dan pengembangan pertanian. Kementrian pertanian.

Burke, T. E. 2005. Conservation Assessment for Four Species of the Genus Hemphillia. USDA Forest Service Region 6 and USDI
Bureau of Land Management, Oregon and Washington. USA.

Campbell, N. A dan Reece, J. B. 2010. Biologi. Edisi ke-8. Jilid 2. Diterjemahkan oleh: Wulandari, D. T. Erlangga. Jakarta.

Hanafiah, K. A., Napoleon, A., dan Nuni, G. 2005. Biologi Tanah Ekologi dan Makrobiologi Tanah. Raja Grafindo Persada, Jakarta.

Michael, P. 1995. Metode Ekologi Untuk Penyelidikan Ladang dan Laboratorium. Diterjemahkan oleh Koestoer, Y. R. UI-Press. Jakarta.

Sinaga, B. I. L. J., Mariani, S., Alida, L. 2015. Dampak Ketebalan Abu Vulkanik Erupsi Gunung Sinabung Terhadap Sifat Biologi Tanah Di Kecamatan Naman Teran Kabupaten Karo. Jurnal Online Agroteknologi. Fakultas Pertanian, Universitas Sumatera Utara. 3 (3): 1159-1163..

Sugiyarto. 2005. Struktur dan komposisi makrofauna tanah sebagai bioindikator kesehatan tanah pada kasus perubahan sistem penggunaan lahan di HTI sengon. BioSMART. 7(2): $100-103$.

Suin, N. M . 2006. Ekologi Hewan Tanah. Edisi ke-3. Bumi Aksara. Jakarta.

Wallwork, J. A. 1970. Ecology of Soil Animal. Mc.Graw Hill Book Company. London.

Wibowo, C. dan Syamsudin, A. S. 2017. Keanekaragaman Makrofauna Tanah pada Berbagai Tipe Tegakan di Areal Bekas Tambang Silika di Holcim Educational Forest, Sukabumi Jawa Barat. Jurnal Silvikultur Tropika. Institut Pertanian Bogor. 8 (1) : 26-34.

Yulipriyanto, H. 2010. Biologi Tanah dan Strategi Pengelolaanya. Graha Ilmu. Yogyakarta. 